Estera Twardow ska-staszek

ORCID: 0000-0001-5499-7393

Akademia Ignatianum w Krakowie

Małgorzata Alberska

ORCID: 0000-0002-2021-4888

Akademia Ignatianum w Krakowie

\title{
Inteligencja emocjonalna i kompetencje społeczne nauczycieli szkół specjalnych
}

\section{Emotional Intelligence and Social Competences} of Special Schools Teachers

\begin{abstract}
ABSTRAKT
Artykuł podejmuje tematykę inteligencji emocjonalnej i kompetencji społecznych nauczycieli. Po wprowadzeniu teoretycznym zostały przedstawione założenia metodologiczne oraz wyniki badań własnych. Przedmiotem badań była inteligencja emocjonalna i kompetencje społeczne nauczycieli szkół specjalnych dla dzieci i młodzieży z niepełnosprawnościq intelektualnq. Celem badań było określenie poziomu oraz ocena poszczególnych aspektów inteligencji emocjonalnej i kompetencji społecznych badanych nauczycieli. Podstawowym problemem badawczym było zatem pytanie: Jak kształtuje się poziom inteligencji emocjonalnej i kompetencji społecznych badanych nauczycieli? Badania zostały przeprowadzone za pomoca dwóch wystandaryzowanych narzędzi badawczych: Popularnego Kwestionariusza Inteligencji Emocjonalnej (PKIE) oraz Profilu Kompetencji Społecznych PROPOS. W badaniu wzięło udział 100 nauczycieli pracujących w szkołach specjalnych lub ośrodkach szkolno-wychowawczych dla
\end{abstract}

SLOWA KLUCZOWE inteligencja emocjonalna, kompetencje społeczne, kompetencje emocjonalno-społeczne nauczycieli

KEYWORDS

emotional intelligence, social competences, emotional-social competences of teachers

SPI Vol. 23, 2020/4 ISSN 2450-5358 e-ISSN 2450-5366 DOI: 10.12775/SPI.2020.4.005 Nadestano: 29.06.2020 Zaakceptowano: 07.10.2020 Raporty z badań 
dzieci i młodzieży z niepełnosprawnościq intelektualnq $190 \%$ kobiet, 10\% mężczyzn; średnia wieku 45 lat). Wyniki badań wskazuja, że ogólny poziom inteligencji emocjonalnej oraz kompetencji społecznych badanych nauczycieli jest na średnim poziomie $(6,61$ stena; 6,19). Jeśli zaś chodzi o poszczególne aspekty inteligencji emocjonalnej, to badani wysokie wyniki uzyskali w skali kontroli własnych stanów emocjonalnych $(7,15$ stena). Biorqc pod uwagę, że poziom kompetencji emocjonalno-społecznych nauczycieli jest zwiqzany z poziomem tych kompetencji uczniów, zaleca się promowanie rozwoju tych kompetencji u nauczycieli już na poziomie kształcenia akademickiego.

\section{ABSTRACT}

The article deals with the subject of emotional intelligence and social competences of teachers. After a theoretical introduction, methodological assumptions and research results have been presented. The subject of the research was emotional intelligence and social competences of the teachers of special schools for children and young people with intellectual disabilities. The aim of the research was to determine the level of individual aspects of emotional intelligence and social competences of the examined teachers, and its assessment. Therefore, the basic research problem is the following question: How is the level of emotional intelligence and social competences of the surveyed teachers shaped? The research has been conducted using two standardized research tools: Popularny Kwestionariusz Inteligencji Emocjonalnej (PKIE) (in English: Popular Emotional Intelligence Questionnaire) and Profil Kompetencji Społecznych (PROPOS) (in English: Social Competences Profile). The study involved 100 teachers working in special schools or educational centers for children and young people with intellectual disabilities ( $90 \%$ women, 10\% men; average age 45 years). The results of the research indicate that the overall level of emotional intelligence and social competences of the teachers surveyed is at an average level (6.61 sten; 6.19). As far as the individual aspects of emotional intelligence are concerned, the respondents who were examined obtained high scores regarding the scale of control of their own emotional states (7.15 sten). Given that the level of teachers' emotional and social competences is related to the level of these competences in students, it is recommended to promote the development of these competences in teachers as early as at the level of academic. 


\section{Wprowadzenie}

Badania naukowe pokazują, że inteligencja emocjonalna oraz kompetencje społeczne nauczycieli są związane z sukcesami edukacyjnymi i zawodowymi uczniów. Biorąc pod uwage powyższe, rola inteligencji emocjonalnej i kompetencji społecznych wydaje się kluczowa nie tylko z punktu widzenia nauczycieli, ale przede wszystkim z perspektywy samych uczniów. Co więcej, wyposażenie drugiej osoby w podstawową wiedzę, umiejętności i kompetencje, wymaga uprzedniego samodzielnego opanowania ich w takim stopniu, aby był możliwy dalszy przekaz (Kwiatkowski 2015a).

Zarówno UNESCO, jak i OECD zwracają uwagę na konieczność wdrożenia nowych, innowacyjnych rozwiązań w zakresie kształcenia akademickiego, uwzględniających inteligencję emocjonalną oraz kompetencje społeczne (Llorent, Zych, Varo-Millán 2020). W niektórych państwach (m.in. w Stanach Zjednoczonych czy państwach Europy Zachodniej) od wielu lat podejmowane są inicjatywy polityczne mające na celu włączenie elementów edukacji z zakresu kompetencji emocjonalno-społecznych do programu kształcenia akademickiego przyszłych kadr pedagogicznych. Niestety, owe inicjatywy nie zawsze kończą się sukcesem. Zespół amerykańskich badaczy (Brackett, Reyes, Rivers, Elbertson i Salovey 2011 za: Kwiatkowski 2015a) podkreśla, że pomimo solidnych podstaw naukowych, system szkolnictwa wyższego wciąż nie jest w stanie wprowadzić postulowanych przez nich we wspomnianej sferze zmian.

Rozwój kompetencji emocjonalno-społecznych rozpoczyna się w chwili urodzenia, pierwszymi nauczycielami są rodzice, następnie, w miarę poszerzania się przestrzeni społecznej - nauczyciele wychowywania przedszkolnego oraz nauczyciele nauczania zintegrowanego. Jeśli wspomniane osoby wyposażą dziecko nie tylko w wiedzę, ale także w zdolności do rozpoznawania i radzenia sobie z własnymi emocjami, w zdolności rozumienia i regulacji emocji innych osób, $\mathrm{w}$ umiejętności radzenia sobie $\mathrm{z}$ wyzwaniami, jakie stają przed nim na różnych etapach życia, to takie dziecko ma szansę osiągać sukcesy życiowe nie tylko na drodze szkolnej czy zawodowej, ale także, a może przede wszystkim, osobistej.

Biorąc pod uwagę, że poziom kompetencji emocjonalno-społecznych nauczycieli koreluje $\mathrm{z}$ poziomem kompetencji uczniów 
(Sutton, Wheatley 2003), ważne jest prowadzenie badań naukowych na temat poziomu tych kompetencji i czynników wpływających na ich wzrost u nauczycieli. Dlatego za podstawowy cel niniejszych badań przyjęto określenie ogólnego poziomu oraz ocenę poszczególnych aspektów inteligencji emocjonalnej i kompetencji społecznych nauczycieli szkół specjalnych dla dzieci i młodzieży z niepełnosprawnością intelektualną. Wiedza na temat inteligencji emocjonalnej i kompetencji społecznych, a zwłaszcza na temat deficytów w tych obszarach, jest o tyle ważna, że może pomóc w zrozumieniu źródeł trudności doświadczanych w pracy zawodowej wymagającej bliskich interakcji społecznych. Co więcej, świadomość własnych braków w tym zakresie jest tym ważniejsza, że obie kompetencje można rozwijać i doskonalić.

\section{Inteligencja emocjonalna}

Od kilku lat, zarówno wśród badaczy, jak i psychologów praktyków, coraz powszechniejszy staje się pogląd, aby inteligencję postrzegać jako szerszy konstrukt obejmujący także zdolności warunkujące dobre funkcjonowanie społeczne.

Pojęcie inteligencji emocjonalnej zostało wprowadzone na początku lat 90. minionego wieku przez Petera Saloveya i Jacka Mayera (1990), a rozpowszechnione za sprawą książki pt. Inteligencja emocjonalna autorstwa Daniela Golemana (1995; 1997). Od tamtej pory stało się niezwykle popularne w publikacjach naukowych, ale też $\mathrm{w}$ języku potocznym.

W literaturze wyróżnia się dwa główne modele inteligencji emocjonalnej: pierwszy, autorstwa Saloveya i Mayera, to model zdolnościowy, traktujący inteligencję emocjonalną jako zdolność lub jako zespół zdolności, drugi, autorstwa Golemana i Reuvena Bar-Ona, to model mieszany, który odnosi inteligencję emocjonalną do kompetencji lub zbioru cech osobowości (Sadowska, Brachowicz 2008).

W pierwszym modelu inteligencja emocjonalna definiowana jest jako

[...] umiejętność właściwej percepcji, oceny i wyrażania emocji, umiejętność dostępu do uczuć, zdolność ich generowania w momentach, gdy mogą wspomóc myślenie, umiejętność rozumienia emocji i zrozumienie wiedzy emocjonalnej oraz umiejętność regulowania emocji 
tak, by wspomagać rozwój emocjonalny i intelektualny (Salovey, Mayer 1999: 34).

Zatem według autorów inteligencja emocjonalna oznacza: a) zdolności do spostrzegania i wyrażania emocji, b) zdolności do asymilowania emocji w przebieg procesów poznawczych, innymi słowy do emocjonalnego wspomagania myślenia, c) zdolności do rozumienia i analizowania emocji oraz d) zdolności do kierowania emocjami - kontrolowania ich i regulowania. Wymienione cztery główne komponenty inteligencji emocjonalnej stanowią podstawę do adekwatnych reakcji emocjonalnych oraz radzenia sobie w sytuacjach społecznych.

W koncepcji Golemana inteligencja emocjonalna określana jest jako

[...] mądrość, która jest podstawą pozostałych struktur w psychice, obejmuje zdolność motywacji i wytrwałości w dążeniu do celu mimo niepowodzeń, umiejętność panowania nad popędami i odłożenia na później ich zaspokajania, regulowania nastroju i niepoddawania się zmartwieniom upośledzającym zdolność myślenia, wczuwania się w nastroje innych osób i optymistycznego patrzenia w przyszłość (Goleman 2007: 67).

Powyższe rozumienie inteligencji emocjonalnej podkreśla rolę uczuć $\mathrm{w}$ interakcjach intrapersonalnych, jak również interpersonalnych. Innymi słowy, według autora, inteligencja emocjonalna zawiera 5 komponentów: a) świadomość swoich stanów emocjonalnych, b) kontrolowanie i kierowanie emocjami, c) motywowanie siebie, d) umiejętność rozpoznawania emocji innych osób (empatia) oraz e) działania na rzecz kontynuowania interakcji $z$ otoczeniem (Sadowska, Brachowicz 2008).

Z kolei Bar-On określa inteligencję emocjonalną jako „szereg pozapoznawczych zdolności, kompetencji i umiejętności, które umożliwiają człowiekowi efektywne radzenie sobie $z$ wymaganiami i naciskami środowiskowymi” (Bar-On 1997 za: Taracha 2010: 64-65). Według tego badacza zawiera ona pięć głównych komponentów: a) umiejętności intrapersonalne, b) umiejętności interpersonalne, c) zdolności przystosowawcze, d) odporność na stres oraz e) ogólny nastrój (Sadowska, Brachowicz 2008). 
Obie powyższe koncepcje łączą w sobie różne aspekty poznania, inteligencji, emocji, motywacji czy osobowości, dlatego są nazywane modelem mieszanym.

Wielu autorów używa terminu kompetencje emocjonalne, wskazując na jego szersze znaczenie. Pojęcie to zostało wprowadzone przez Stevena Gordona, a spopularyzowane za sprawą książki The Development of Emotional Competence autorstwa Carolyn Saarni. Koncepcja kompetencji emocjonalnych Saarni wywodzi się przede wszystkim $z$ teorii socjologicznych, stąd silny związek między inteligencją emocjonalną i jej konsekwencjami natury społecznej. Zdaniem autorki „kompetencje emocjonalne jest to prowadząca do rozwoju jednostki zdolność angażowania się w transakcje w zmiennym i niekiedy niesprzyjającym środowisku społeczno-fizycznym" (Saarni 1999: 79). Kompetencje emocjonalne zatem, oznaczają aktywne uczestnictwo w życiu społecznym. Co więcej, wysoki poziom tych kompetencji powoduje kierowanie swoimi myślami, emocjami i działaniami adekwatnie w kontekście społeczno-kulturowym. Ujęcie Saarni jest nieco szersze od propozycji Saloveya i Mayera czy Golemana i Bar-Ona, ponieważ autorka wyraźnie podkreśla, że kluczową rolę w emocjonalnym funkcjonowaniu człowieka odgrywa społeczny kontekst.

Wyniki wielu badań wskazują na związek pomiędzy wysokim poziomem inteligencji emocjonalnej a lepszymi ocenami i większą kontrolą emocji u uczniów (Gil-Olarte, Guil, Mestre i Nuñez 2005; Gil-Olarte, Palomera, Brackett 2006). Christopher Trentacosta i Caroll Izard (2007) wykazali, że kompetencje emocjonalno-społeczne dzieci w wieku przedszkolnym rzutują na ich wyniki w nauce w wieku szkolnym. Należy jednak mieć na uwadze, że spostrzeganie i rozumienie własnych emocji, a także umiejętność samoregulacji nie są wystarczającymi predyktorami sukcesów życiowych. Równie ważne, a może nawet ważniejsze, jest spostrzeganie, rozumienie i regulowanie stanów emocjonalnych innych osób, szczególnie w tych obszarach aktywności życiowych, w których ważna jest interakcja z drugim człowiekiem (Jaworowska, Matczak 2005).

Biorąc pod uwagę powyższe, rola inteligentnego emocjonalnie nauczyciela w procesie opieki, wychowania i kształcenia jest kluczowa.

Jak pisze Goleman, tym, co czyni z nauczyciela dobrego przywódcę, jest właśnie mądrość emocjonalna. Inteligentny emocjonalnie 
nauczyciel tak wychowuje i kształci, aby uczeń nie tylko myślał i działał, ale także przeżywał, gdyż według tego autora „wspaniała praca zaczyna się od wspaniałych i silnych uczuć” (Goleman 1997: 156; 1999: 259).

Jak już zostało wspomniane we Wprowadzeniu, zespół amerykańskich badaczy (Brackett i in. 2011 za: Kwiatkowski, 2015a) analizował właściwości emocjonalnego klimatu klasy szkolnej (classroom emotional climate - CEC), określanego jako stopień, w jakim nauczyciele potrafią sprzyjać tworzeniu w klasie atmosfery charakteryzującej się poczuciem komfortu uczniów oraz dominacją pozytywnych emocji. Emocjonalny klimat klasy szkolnej zaspokaja potrzebę bezpieczeństwa, przywiązania, aprobaty i uznania, a także wzmacnia motywację do nauki, rozbudza zainteresowania, sprzyja konstruktywnym sposobom radzenia sobie w sytuacjach trudnych. Obok wymienionych cech ważne miejsce w opisie emocjonalnego klimatu klasy szkolnej zajmuje nauczyciel i jego cechy, tj. wrażliwość na potrzeby uczniów, ciepłe, przyjazne i pełne zrozumienia relacje nauczyciel-uczeń, szacunek dla uczniów i odnoszenie się do ich punktu widzenia oraz zachęcanie ich do aktywnego uczestnictwa w zajęciach oraz brak nieprzyjemnych praktyk dyscyplinujących i cynizmu (Hamre i Pianta 2007 za: Kwiatkowski 2015a).

Powyższe analizy dowodzą, że inteligencja emocjonalna wydaje się stanowić pierwszorzędną zdolność w pracy nauczyciela. Bycie wychowawcą, pedagogiem, a zwłaszcza pedagogiem specjalnym, związane jest $z$ dużym obciążeniem emocjonalnym wynikającym z licznych interakcji: nauczyciel-uczeń, nauczyciel-rodzic, nauczyciel-nauczyciel, nauczyciel-dyrektor itp. W tej optyce świadomość i rozumienie własnych emocji, a także ich kontrola, są zdolnościami niezbędnymi w prawidłowym funkcjonowaniu zawodowym. Co więcej, nie wystarczy tylko rozumieć własne stany emocjonalne, ale przede wszystkim emocje i wynikające $z$ nich zachowania uczniów, szczególnie tych, których deficyty intelektualne nie pozwalają na ich adekwatne wyrażanie i komunikowanie. Brak kompetencji emocjonalnych, a mianowicie brak świadomości własnych i cudzych emocji, wyklucza bycie dobrym nauczycielem. 


\section{Kompetencje społeczne}

Innym, ważnym wyznacznikiem funkcjonowania człowieka w roli społecznej, w tym zawodowej, są kompetencje społeczne.

Pojęcie kompetencji społecznych zostało wprowadzone przez Roberta W. White'a w 1959 roku. White zajmował się problematyką wywierania wpływu na otoczenie. Ujmował ją jako specyficznie rozumianą umiejętność, czyli każdą taką umiejętność, która przyczynia się do skutecznej interakcji z otoczeniem, utożsamiając ją ze społecznymi umiejętnościami. Od tego czasu liczni badacze próbują stworzyć jak najbardziej adekwatną definicję kompetencji społecznych, zastanawiając się, czy można mówić o jednej, ogólnej kompetencji, czy raczej o zbiorze różnych kompetencji, które wiążą się z różnymi obszarami funkcjonowania społecznego. Niektórzy utożsamiają je z inteligencją emocjonalną i społeczną, jak również z wiedzą społeczną. Inni zaś opierają się na procesach poznawczych, a w szczególności na zdolności pozyskiwania informacji o znaczeniu społecznym i ich selekcjonowaniu. Nie brakuje także podejść uwzględniających aspekty motywacyjne, a także temperament i osobowość. Jednak, zdaniem Katarzyny Martowskiej (2012), dopiero zastosowanie tego w przestrzeni społecznej można nazwać kompetencją społeczną. Tak czy inaczej, można się zgodzić ze stwierdzeniem, że kompetencje społeczne mają złożoną naturę.

Najogólniej stwierdzając, kompetencje społeczne są umiejętnościami, które warunkują sprawność zarządzania sobą w sytuacjach społecznych i skuteczność $\mathrm{w}$ sytuacjach interpersonalnych (Smółka 2008: 258).

Anna Matczak definiuje kompetencje społeczne jako „złożone umiejętności warunkujące efektywność radzenia sobie w określonego typu sytuacjach społecznych, nabywane przez jednostkę w toku treningu społecznego" (Matczak 2007: 7). Innymi słowy, kompetencje społeczne to zdolności człowieka do efektywnego radzenia sobie w sytuacjach społecznych (Matczak, Martowska 2013). Przy czym sytuacje te odnoszą się zarówno do najbliższego otoczenia - rodziny, jak i do szerszego otoczenia społecznego - jak szkoła czy praca.

Kompetencje społeczne należą do ośmiu wyróżnionych przez Unię Europejską kompetencji kluczowych. Według UE stanowią 
połączenie wiedzy, umiejętności i postaw odpowiednich do danej sytuacji, w jakiej znajduje się człowiek.

Pojęcie kompetencji społecznych akcentuje dwie ich funkcje: a) nawiązanie i utrzymanie relacji interpersonalnych oraz b) realizowanie własnych celów dzięki wywieraniu wpływu na innych. Biorąc pod uwage powyższe, należy się zastanowić, czy istnieje ogólna dyspozycja do bycia kompetentnym, co w konsekwencji przekłada się na radzenie sobie w każdym ze wspomnianych obszarów społecznego funkcjonowania? Czy raczej jest to zbiór zdolności, który skutkuje różnym poziomem radzenia sobie $\mathrm{w}$ różnych sytuacjach interpersonalnych? Odpowiedź na to pytanie dzieli badaczy, jednakże autorki badań przychylają się do poglądu o specyficznych kompetencjach społecznych, co odzwierciedla się użytym w badaniach kwestionariuszu.

W tej optyce pojawia się pytanie o ilość i rodzaj kompetencji społecznych. Ronald Riggio (1986) wymienia ich siedem (ekspresywność emocjonalna, wrażliwość emocjonalna, kontrola emocjonalna, ekspresywność społeczna, wrażliwość społeczna, kontrola społeczna, oraz manipulacja społeczna), natomiast Michael Argyle (1999) sześć (umiejętność nagradzania, umiejętność empatyzowania i podejmowania ról, asertywność, umiejętność komunikowania się werbalnego, umiejętność komunikowania się niewerbalnego i umiejętność korzystnej autoprezentacji). Jeszcze inne grupy kompetencji społecznych, oparte jednak na kategoryzacji Argyle’a, wyróżnia Matczak (2001), autorka Kwestionariusza Kompetencji Społecznych: umiejętności radzenia sobie w sytuacji bliskiego kontaktu interpersonalnego, w sytuacjach ekspozycji społecznej oraz w sytuacjach wymagających asertywności.

Badania dotyczące kompetencji społecznych i ich wpływu na funkcjonowanie człowieka w różnych obszarach życia są prowadzone niemal na całym świecie. Wyniki badań wskazują, że istnieje zależność między umiejętnościami poznawczymi i właśnie kompetencjami społecznymi a sukcesami $\mathrm{w}$ trakcie nauki szkolnej oraz, już po jej zakończeniu, w dorosłym życiu zawodowym (Jones, Greenberg, Crowley 2015).

Inne badania wskazują na dodatnią korelację pomiędzy kompetencjami społecznymi a poczuciem zadowolenia, chęcią niesienia pomocy innym, ale także otwartością do przyjmowania pomocy od 
innych. Co więcej, zauważono, że osoby z wysokim poziomem kompetencji społecznych lepiej radzą sobie w sytuacjach trudnych oraz mają pozytywne interakcje społeczne. Ujemna korelacja występuję między kompetencjami społecznymi a zaburzeniami psychicznymi, uzależnieniami, chorobami somatycznymi (Knopp 2013). Wysoki poziom kompetencji społecznych wspiera nauczycieli w radzeniu sobie ze stresem, jaki w ostatnich latach, w skomplikowanej rzeczywistości edukacyjnej, towarzyszy pedagogom. W badaniach obciążeń zawodowych nauczycieli, prowadzonych przez Stefana Kwiatkowskiego (2018a, 2018b), autor stwierdza, że stres zwiększa prawdopodobieństwo występowania negatywnych konsekwencji w obszarze szeroko pojętego psychicznego dobrostanu nauczycieli.

Kompetencji społecznych nabywa się w drodze treningu społecznego. Pierwszymi wzorami do naśladowania są rodzice, później nauczyciele. Rola nauczycieli w kształtowaniu kompetencji nabiera szczególnego znaczenia w okresie przedszkolnym i wczesnoszkolnym, ponieważ w tym okresie dzieci większość czasu w ciągu dnia spędzają w przedszkolu lub szkole. Tam nauczyciel ma możliwość obserwowania ucznia podczas wielu różnorodnych sytuacji, w których niezbędne są kompetencje społeczne. Świadomy nauczyciel doskonale potrafi rozpoznać te obszary, w których dziecko wymaga wsparcia i korektywnych wzorów zachowań. Jeśli nauczyciel sam posiada deficyty w tych zakresach, nie będzie dobrym modelem dla wychowanka. Natomiast jeśli poziom jego kompetencji jest wysoki, może być dobrym przewodnikiem w wyzwaniach, które stają przed młodym człowiekiem.

\section{Założenia mełodologiczne badań własnych}

Przedmiotem przedstawionych poniżej wyników badań była inteligencja emocjonalna i kompetencje społeczne nauczycieli szkół specjalnych dla dzieci i młodzieży z niepełnosprawnością intelektualną.

Celem badań było określenie ogólnego poziomu oraz ocena poszczególnych aspektów inteligencji emocjonalnej i kompetencji społecznych badanych nauczycieli. Dodatkowo uwzględnione zostały takie zmienne jak płeć, wiek oraz staż pracy.

Przedmiot empirycznych weryfikacji koncentrował się zatem wokół głównego problemu badawczego: Jak kształtuje się inteligencja 
emocjonalna i kompetencje społeczne nauczycieli szkół specjalnych? Biorąc pod uwagę powyższe, sformułowano następujące badania szczegółowe:

1. Jaki jest poziom inteligencji emocjonalnej badanych nauczycieli?

2. Jaki jest poziom kompetencji społecznych badanych nauczycieli?

3. Czy i w jaki sposób płeć, wiek i staż pracy nauczycieli są czynnikami różnicującymi inteligencję emocjonalną badanych?

4. Czy i w jaki sposób płeć, wiek i staż pracy nauczycieli są czynnikami różnicującymi kompetencje społeczne badanych?

Dane empiryczne zebrano za pomocą Popularnego Kwestionariusza Inteligencji Emocjonalnej (PKIE), kwestionariusza PROPOS oraz kwestionariusza ankiety.

Popularny Kwestionariusz Inteligencji Emocjonalnej (Jaworowska, Matczak 2005) jest narzędziem samoopisowym. Składa się z 94 itemów, z których każdy sformułowany jest $\mathrm{w}$ formie stwierdzenia (np. Często nie potrafię opisać tego, co czuję). Badany ma za zadanie wskazać na pięciostopniowej skali stopień, w jakim zgadza się z danym stwierdzeniem (1 - zdecydowanie nie zgadam się, 2 - raczej nie zgadzam się, 3 - trudno powiedzieć, 4 - raczej się zgadzam, 5 zdecydowanie zgadzam się). Uzyskane odpowiedzi dają podstawy do obliczenia wyniku ogólnego oraz wyników w zakresie czterech skal:

1. AKC - akceptowanie, wyrażanie i wykorzystywanie własnych emocji w działaniu,

2. EMP - empatia, czyli rozumienie i rozpoznawanie emocji innych ludzi,

3. KON - kontrola, także poznawcza, nad własnymi emocjami,

4. ROZ - rozumienie i uświadamianie sobie własnych emocji.

Właściwości psychometryczne skali są bardzo dobre (rzetelność: współczynnik alfa Cronbacha dla wyniku ogólnego dla uczniów i dorosłych wynosi powyżej 0,90 ; trafność czynnikowa: cztery czynniki wyjaśniają 24,5\% [uczniowie] i 32,8\% [dorośli] wariancji całkowitej).

Kwestionariusz PROKOS (Matczak, Martowska 2013) jest narzędziem samoopisowym, składającym się z 90 pozycji, z których każda określa różne czynności lub zadania. Czynności te odnoszą się do trzech obszarów aktywności społecznej człowieka: pracy zawodowej, życia towarzyskiego i życia rodzinnego. Badany ma ocenić za pomocą 
czterostopniowej skali, jak dobrze poradziłby sobie w określonej sytuacji (np. Na spotkaniu towarzyskim zainicjować rozmowę z nieznana Ci osobq). Skala ta ma następujące kategorie odpowiedzi: 4 - zdecydowanie dobrze, 3 - raczej dobrze, 2 - raczej słabo, 1 - zdecydowanie źle. Badany uzyskuje wynik ogólny oraz wyniki w zakresie pięciu skal:

1. Skala A - mierząca kompetencje asertywne,

2. Skala $\mathrm{K}$ - mierząca kompetencje kooperacyjne,

3. Skala $\mathrm{T}$ - mierząca kompetencje towarzyskie,

4. Skala $Z$ - mierząca zaradność społeczną,

5. Skala $\mathrm{S}$ - mierząca kompetencje społecznikowskie.

Właściwości psychometryczne skali są bardzo dobre (rzetelność: współczynnik alfa Cronbacha wynosi 0,95; trafność wyniku ogólnego ustalona na podstawie korelacji wyników PROKOS z m.in. kompetencjami społecznymi mierzonymi KKS, z inteligencją emocjonalną).

W badaniach wzięło udział 100 nauczycieli pracujących w szkołach specjalnych lub ośrodkach szkolno-wychowawczych dla dzieci i młodzieży z niepełnosprawnością intelektualną. Wśród nich było 90\% kobiet i 10\% mężczyzn. Średnia wieku wynosiła 45 lat. Średnia stażu w pracy z osobami z niepełnosprawnością intelektualną wynosiła 21 lat. Wszyscy nauczyciele pracowali z dziećmi i młodzieżą z orzeczeniem o niepełnosprawności: $2 \%$ z uczniami z lekką niepełnosprawnością intelektualną, 76\% - z umiarkowaną, 75\% - ze znaczną oraz $66 \%$ - z głębokąa ${ }^{1}$.

Przeprowadzenie badań poprzedzone było spotkaniem z dyrektorami placówek, podczas których wyjaśniono cel badań i opisano narzędzia badawcze. Po uzyskaniu zgód dyrektorów na przeprowadzenie badań wśród nauczycieli rozdano kwestionariusze. Uczestnicy badań zostali poinformowani o tym, że udział jest dobrowolny, anonimowy, a uzyskane dane empiryczne będą wykorzystane tylko w celach naukowych. Część nauczycieli wypełniła kwestionariusze w szkole, część w domu. Połowa rozdanych kwestionariuszy nie została zwrócona.

Analizę zmiennych ilościowych (tj. wyrażonych liczbą) przeprowadzono wyliczając średnią, odchylenie standardowe, medianę, kwartyle, minimum oraz maksimum. Porównanie wartości zmiennych ilościowych w dwóch grupach wykonano za pomocą testu

1 Procenty nie sumują się do 100 , gdyż było to pytanie wielokrotnego wyboru. 
t-Studenta (gdy zmienna miała w tych grupach rozkład normalny) lub testu Manna-Whitneya (w przeciwnym przypadku). Korelacje między zmiennymi ilościowymi analizowano za pomocą współczynnika korelacji Pearsona (gdy obie miały rozkład normalny) lub Spearmana (w przeciwnym przypadku). Analizę wykonano w programie $\mathrm{R}$, wersja 3.5.12.

\section{Analiza i interpretacja wyników badań empirycznych}

Kwestionariusz PKIE pozwala ocenić inteligencję emocjonalną badanego w czterech skalach: AKC - akceptowanie, wyrażanie i wykorzystywanie własnych emocji w działaniu, EMP - empatia, czyli rozumienie i rozpoznawanie emocji innych ludzi, KON - kontrola, także poznawcza, nad własnymi emocjami oraz $\mathrm{ROZ} \mathrm{-} \mathrm{rozumienie}$ i uświadamianie sobie własnych emocji. Dodatkowo wylicza się też wynik łączny. Dla każdej ze skal oraz dla wyniku łącznego istnieją normy stenowe (osobne dla kobiet i mężczyzn) pozwalające interpretować wyniki w kategoriach wyników niskich (steny 1-4), średnich (steny 5-6) i wysokich (steny 7-10). Poniżej, w formie tabelarycznej i graficznej, przedstawiono wyniki uzyskane przez badanych w kwestionariuszu PKIE.

Tabela 1. Poziom inteligencji emocjonalnej

\begin{tabular}{|l|c|c|c|c|}
\hline & Wyniki niskie & Wyniki średnie & Wyniki wysokie & Średni sten \\
\hline AKC & $30(30 \%)$ & $33(33 \%)$ & $37(37 \%)$ & 5,56 \\
\hline EMP & $23(23 \%)$ & $22(22 \%)$ & $55(55 \%)$ & 6,18 \\
\hline KON & $12(12 \%)$ & $21(21 \%)$ & $67(67 \%)$ & 7,15 \\
\hline ROZ & $3(3 \%)$ & $45(45 \%)$ & $52(52 \%)$ & 6,69 \\
\hline Wynik łqczny PKIE & $5(5 \%)$ & $56(56 \%)$ & $39(39 \%)$ & 6,61 \\
\hline
\end{tabular}

AKC - akceptowanie, wyrażanie i wykorzystywanie własnych emocji w działaniv, EMP - empatia, czyli rozumienie i rozpoznawanie emocji innych ludzi, KON - kontrola, także poznawcza, nad własnymi emocjami oraz ROZ - rozumienie i uświadamianie sobie własnych emocji.

Źródło: badania własne.

2 R Core Team (2018). R: A language and environment for statistical computing. R Foundation for Statistical Computing, Vienna, Austria. https:// www.R-project.org/. 
Uzyskane dane pokazują, że badani nauczyciele najwyższy wynik uzyskali w skali $\mathrm{KON}$ (7,15 stena, a więc wynik wysoki), innymi słowy, dominuje u nich zdolność do kontrolowania własnych emocji. Badani potrafią świadomie sterować własnymi emocjami, co jest szczególnie ważne w pracy pedagoga specjalnego. Praca $z$ dziećmi i młodzieżą z niepełnosprawnością intelektualną wymaga bardzo często dostosowywania natężenia i sposobów wyrażania uczuć do specyfiki danego ucznia, jak i danej sytuacji społecznej. Wysoki wynik tej skali wskazuje także, że badani nauczyciele posiadają wiedzę, jakie stany emocjonalne wspierają, a jakie utrudniają wykonywanie poszczególnych rodzajów działań, co więcej, potrafią wykorzystać tę wiedzę w oddziaływaniach pedagogicznych. Badani nauczyciele uzyskali średnie, ale bardzo blisko wysokich wyników w skali $\operatorname{EMP~}(6,18$ stena) oraz ROZ (6,69 stena). Interpretując te wyniki, można stwierdzić, że badani mają samoświadomość własnych uczuć i ich przyczyn. Dodatkowo badani trafnie odczytują i rozumieją emocje innych osób, przed co rozumieją intencje ich działań. Umiejętność rozpoznawania i rozumienia stanów emocjonalnych osób jest kluczowa w pracy z osobami z niepełnosprawnością intelektualną, bowiem jest to grupa osób, która w zależności od stopnia niepełnosprawności ma trudności w wyrażaniu uczuć. Badani nauczyciele najniższe wyniki uzyskali w skali AKC (5,56 stena, a więc wynik średni), innymi słowy badani mają przeciętne umiejętności wyrażania własnych uczuć, zarówno pozytywnych, jak i negatywnych. Konsekwencją średnich wyników w tej skali mogą być trudności osób niepełnosprawnych intelektualnie w zrozumieniu co przeżywa nauczyciel i jak adekwatnie reagować na jego stany emocjonalne. Średni wynik łączny PKIE to 6,61 stena, a więc poziom średni, choć już bardzo blisko wysokiego. 
Wykres 1. Poziom inteligencii emocionalnej

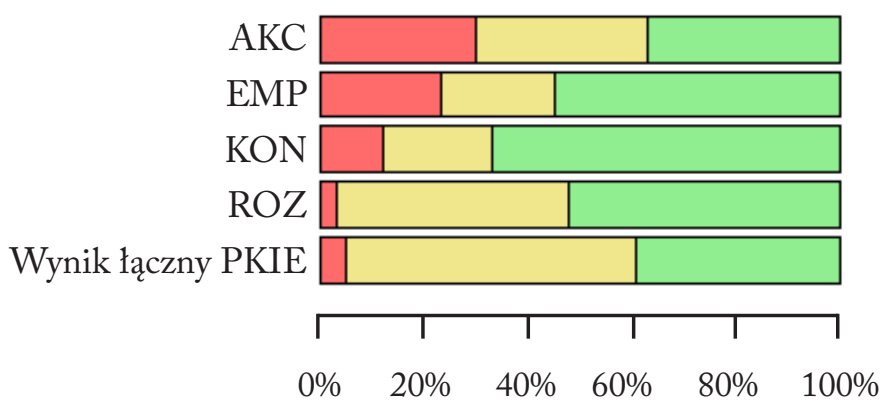

$\square$ Wyniki niskie $\square$ Wyniki średnie $\square$ Wyniki wysokie

Źródło: badania własne.

Podsumowując powyższe analizy, konieczne jest trenowanie tych komponentów inteligencji emocjonalnej, w której pedagodzy specjalni mają średnie wyniki, tj. akceptowania, wyrażania i wykorzystywania własnych emocji w działaniu, zdolności do empatii oraz zdolności do rozumienia i uświadamiania sobie własnych emocji. Jak już zostało wcześniej wspomniane, są to bowiem zdolności, które można doskonalić.

Kwestionariusz PROKOS (Profil Kompetencji Społecznych) pozwala na ocenę poziomu kompetencji społecznych w pięciu zakresach szczególowych: kompetencji asertywnych (skala A), kompetencji kooperacyjnych (skala K), kompetencji towarzyskich (skala $\mathrm{T}$ ), zaradności społecznej (skala $Z$ ), kompetencji społecznikowskich (skala S). Dodatkowo wylicza się też wynik łączny. Dla każdej z podskal oraz dla wyniku łącznego istnieją normy stenowe (osobne dla kobiet i mężczyzn), pozwalające interpretować wyniki w kategoriach wyników niskich (steny 1-4), średnich (steny 5-6) i wysokich (steny 7-10). Poniżej, w formie tabelarycznej i graficznej, przedstawiono wyniki uzyskane przez respondentów w kwestionariuszu PROKOS. 
Tabela 2. Poziom kompetencji społecznych

\begin{tabular}{|l|c|c|c|c|}
\hline & Wyniki niskie & Wyniki średnie & Wyniki wysokie & Średni sten \\
\hline Skala A & $26(26 \%)$ & $37(37 \%)$ & $37(37 \%)$ & 5,77 \\
\hline Skala K & $19(19 \%)$ & $35(35 \%)$ & $46(46 \%)$ & 6,09 \\
\hline Skala T & $26(26 \%)$ & $34(34 \%)$ & $40(40 \%)$ & 5,97 \\
\hline Skala Z & $28(28 \%)$ & $21(21 \%)$ & $51(51 \%)$ & 6,18 \\
\hline Skala S & $18(18 \%)$ & $38(38 \%)$ & $44(44 \%)$ & 6,51 \\
\hline $\begin{array}{l}\text { Wynik łaczny } \\
\text { PROKOS }\end{array}$ & $25(25 \%)$ & $24(24 \%)$ & $51(51 \%)$ & 6,19 \\
\hline
\end{tabular}

Skala A - kompetencje asertywne, skala K - kompetencje kooperacyine, skala T kompetencje towarzyskie, skala Z - zaradność społeczna, skala S - kompetencje społecznikowskie.

Źródło: badania własne.

Powyższe dane pokazują, że badani nauczyciele uzyskali najwyższe wyniki w skali S (6,51 stena), co świadczy o średnim (ale bardzo blisko wysokiego) poziomie ich kompetencji społecznikowskich. Badani posiadają dobre umiejętności dostrzegania potrzeb i celów społecznych, jak również potrafią organizować działania i włączać w nie inne osoby. Wynik na poziomie 6 stena badani nauczyciele uzyskali także w innych skalach: Z (6,18 stena) oraz K (6,09 stena), czyli zaradności społecznej i kompetencji kooperacyjnych. Badani posiadają przeciętne umiejętności realizowania zadań, zwłaszcza wymagających egzekwowania działań ze strony innych osób. Szczególnie przydane $\mathrm{w}$ pracy z dziećmi i młodzieżą są kompetencje kooperacyjne, bowiem osoba posiadająca wysokie wyniki w tej skali $(\mathrm{K})$ potrafi się zatroszczyć o innych, udzielić im pomocy i wsparcia oraz zgodnie współdziałać. Ponadto, jak podają autorzy kwestionariusza, jest to umiejętność zależna od treningu społecznego. Najniższe wyniki badani uzyskali w skali T, czyli kompetencji towarzyskich $(5,97$ stena) oraz w skali A, czyli kompetencji asertywnych $(5,77)$. Średni wynik łączny PROKOS to 6,19 stena, a więc poziom średni. 
Wykres 2. Poziom kompetencji społecznych

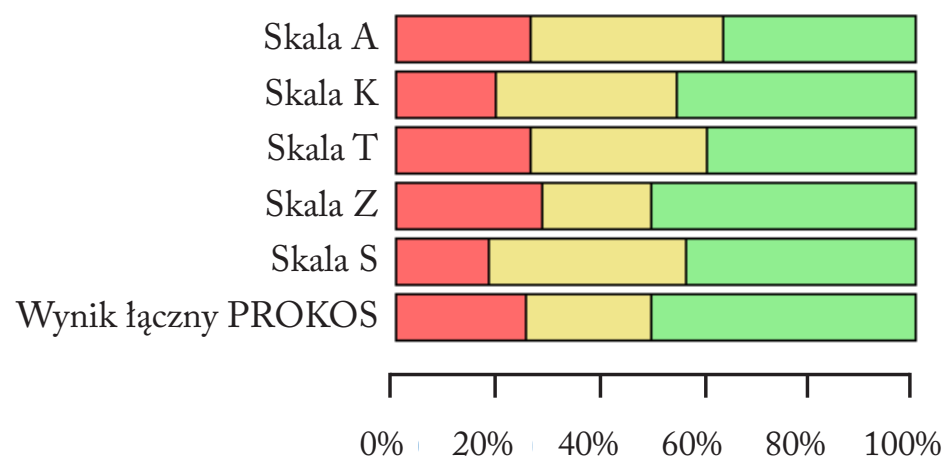

$\square$ Wyniki niskie $\square$ Wyniki średnie $\square$ Wyniki wysokie

Źródło: badania własne.

\section{Płeć a inteligencja emocjonalna i kompetencje społeczne}

Jeśli chodzi o płeć, różne badania pokazują, że poziom inteligencji emocjonalnej jest wyższy u kobiet (zob. Molero, Ortega i Moreno 2010; Zych i in. 2017). Należy jednak mieć na uwadze, że przytoczone badania były przeprowadzone na ogólnej populacji kobiet i mężczyzn, nie zaś na populacji nauczycieli. Natomiast w przeprowadzonych badaniach wśród nauczycieli szkół specjalnych płeć nie jest czynnikiem różnicującym poziom inteligencji emocjonalnej. Ani wynik łączny, ani poszczególne skale nie wykazały istotnej zależności (wszystkie p > 0,05). Można przypuszczać, że zawód pedagoga specjalnego wybierają mężczyźni z szczególnymi predyspozycjami osobowymi.

Inna sytuacja jest w przypadku poziomu kompetencji społecznych. Uzyskane dane pokazują, że mężczyźni uzyskiwali wyższe wyniki niż kobiety w każdej ze skal, jak również w wyniku ogólnym. 
Tabela 3. Płeć a kompetencje społeczne

\begin{tabular}{|c|c|c|c|c|}
\hline \multicolumn{2}{|c|}{ PROKOS } & \multirow{2}{*}{$\begin{array}{c}\text { Kobiety ( } \mathbf{N}=\mathbf{9 0}) \\
5,56 \pm 2,36 \\
\end{array}$} & \multirow{2}{*}{$\begin{array}{c}\text { Mężczyźni } \\
(\mathbf{N}=10)\end{array}$} & \multirow{2}{*}{$\begin{array}{c}\mathbf{p}^{*} \\
0,008\end{array}$} \\
\hline \multirow{3}{*}{ Skala A } & 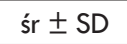 & & & \\
\hline & mediana & 6 & 7,5 & NP \\
\hline & kwartyle & $4-7$ & $6,25-9,5$ & \\
\hline \multirow{3}{*}{ Skala K } & 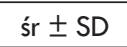 & $5,87 \pm 2,31$ & $8,1 \pm 1,29$ & 0,002 \\
\hline & mediana & 6 & 8 & NP \\
\hline & kwartyle & $5-7$ & $7,25-8,75$ & \\
\hline \multirow{3}{*}{ Skala T } & śr $\pm S D$ & $5,73 \pm 2,22$ & $8,1 \pm 1,73$ & 0,001 \\
\hline & mediana & 6 & 9 & NP \\
\hline & kwartyle & $4-7,75$ & $6,75-9$ & \\
\hline \multirow{3}{*}{ Skala Z } & śr \pm SD & $6,01 \pm 2,48$ & $7,7 \pm 2$ & 0,048 \\
\hline & mediana & 6 & 7,5 & NP \\
\hline & kwartyle & $4-7$ & $6,25-9,75$ & \\
\hline \multirow{3}{*}{ Skala S } & śr $\pm S D$ & $6,34 \pm 2,23$ & $8 \pm 1,76$ & 0,022 \\
\hline & mediana & 6 & 8 & NP \\
\hline & kwartyle & $5-8$ & $6,25-9,75$ & \\
\hline \multirow{3}{*}{$\begin{array}{l}\text { Wynik łaczny } \\
\text { PROKOS }\end{array}$} & 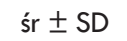 & $5,97 \pm 2,44$ & $8,2 \pm 1,4$ & 0,004 \\
\hline & mediana & 6 & 8 & NP \\
\hline & kwartyle & $4-8$ & $7,25-9,5$ & \\
\hline
\end{tabular}

$* p=$ Rozkład normalny $w$ grupach, test t-Studenta; NP = Brak normalności rozkładu w grupach, test Manna-Whitneya

Źródło: badania własne.

\section{Wiek a inteligencja emocjonalna i kompetencje społeczne}

Niektóre badania wskazują, że ludzie w starszym wieku odznaczają się większą zdolnością regulacji emocjonalnej (zob. Márquez-González, Izal, Montorio, Losada 2008), podczas gdy inne wskazują na coś przeciwnego (zob. Nolen-Hoeksema, Aldao 2011). Przeprowadzone badania sa zgodne $\mathrm{z}$ pierwszym twierdzeniem. Wiek koreluje istotnie i dodatnio ze skalami $\mathrm{KON}$ i ROZ oraz wynikiem łącznym PKIE (gdyż p < 0,05), a więc im starszy wiek, tym wyższe wyniki na tych skalach. Zatem doświadczenie życiowe, które człowiek nabywa wraz z wiekiem, pogłębia samoświadomość własnych uczuć, rozwija zdolności ich nazywania, rozumienia, a także kontrolowania. Należy mieć także na uwadze, że zdobywanie kolejnych poziomów inteligencji emocjonalnej wymaga rozwoju także zdolności poznawczych (Salovey, Sluyter 1999; za: Taracha 2010: 66-69). 
Tabela 4. Wiek a inteligencja emocjonalna

\begin{tabular}{|l|c|c|c|c|}
\hline \multirow{2}{*}{ PKIE } & \multicolumn{4}{|c|}{ Korelacja z wiekiem } \\
\cline { 2 - 5 } & $\begin{array}{c}\text { Współczynnik } \\
\text { korelacji }\end{array}$ & $\mathbf{p} *$ & $\begin{array}{c}\text { Kierunek } \\
\text { zależności }\end{array}$ & Siła zależności \\
\hline AKC & 0,136 & $\mathrm{p}=0,182 \mathrm{NP}$ & --- & --- \\
\hline EMP & 0,191 & $\mathrm{p}=0,059 \mathrm{NP}$ & --- & --- \\
\hline KON & 0,344 & $\mathrm{p}=0,001 \mathrm{NP}$ & dodatni & słaba \\
\hline ROZ & 0,216 & $\mathrm{p}=0,032 \mathrm{NP}$ & dodatni & bardzo słaba \\
\hline Wynik łączny PKIE & 0,335 & $\mathrm{p}=0,001 \mathrm{NP}$ & dodatni & słaba \\
\hline
\end{tabular}

* $p=$ Rozkład normalny obu korelowanych zmiennych, współczynnik korelacji Pearsona; NP = Brak normalności rozkładu przynajmniej jednej z korelowanych zmiennych, współczynnik korelacii Spearmana

Źródło: badania własne.

Analizy dotyczące kompetencji społecznych pokazują, że wiek nie koreluje istotnie z żadną ze skal (gdyż wszystkie p > 0,05).

\section{Staż pracy a inteligencja emocjonalna i kompetencje społeczne}

Staż pracy z osobami z niepełnosprawnością intelektualną koreluje istotnie i dodatnio ze skalami $\mathrm{KON}$ i $\mathrm{ROZ}$ oraz wynikiem łącznym PKIE (gdyż p < 0,05), a więc im dłuższy staż, tym wyższe wyniki na tych skalach.

Tabela 5. Staż pracy a inteligencja emocjonalna

\begin{tabular}{|l|c|c|c|c|}
\hline \multirow{2}{*}{ PKIE } & \multicolumn{3}{|c|}{ Korelacja ze stażem pracy z osobami z niepełnosprawnościq intelektualnq } \\
\cline { 2 - 5 } & $\begin{array}{c}\text { Współczynnik } \\
\text { korelacji }\end{array}$ & $\mathbf{p}^{*}$ & $\begin{array}{c}\text { Kierunek } \\
\text { zależności }\end{array}$ & Siła zależności \\
\hline AKC & 0,112 & $\mathrm{p}=0,272 \mathrm{NP}$ & --- & --- \\
\hline EMP & 0,112 & $\mathrm{p}=0,272 \mathrm{NP}$ & --- & --- \\
\hline KON & 0,347 & $\mathrm{p}<0,001 \mathrm{NP}$ & dodatni & słaba \\
\hline ROZ & 0,271 & $\mathrm{p}=0,007 \mathrm{NP}$ & dodatni & bardzo słaba \\
\hline Wynik łq̨czny PKIE & 0,298 & $\mathrm{p}=0,003 \mathrm{NP}$ & dodatni & bardzo słaba \\
\hline
\end{tabular}

* $\mathrm{p}=$ Rozkład normalny obu korelowanych zmiennych, współczynnik korelacji Pearsona; NP = Brak normalności rozkładu przynajmniej jednej z korelowanych zmiennych, współczynnik korelacji Spearmana

Źródło: badania własne. 
Biorąc pod uwagę powyższe, zarówno wiek i jak i staż pracy powodują doskonalenie zdolności do odczuwania, rozumienia i kontrolowania własnych stanów emocjonalnym. $U$ badanych staż pracy szedł w parze $\mathrm{z}$ wiekiem, stąd podobne rezultaty empiryczne. Natomiast staż pracy z osobami z niepełnosprawnością intelektualną nie koreluje istotnie $\mathrm{z}$ żadną ze skal w zakresie kompetencji społecznych (gdyż wszystkie $\mathrm{p}>0,05$ ).

\section{Zakończenie}

Poziom inteligencji emocjonalnej i kompetencji społecznych powinien determinować wybór zawodu, ponieważ istnieją obszary aktywności zawodowej człowieka, w której jest ona szczególnie ważna. Do takich aktywności należy właśnie praca nauczycie1a. Zawód ten, obdarzony szczególnym zaufaniem społecznym, ale i ogromnymi oczekiwaniami, wymaga ustawicznego aktualizowania kompetencji, otwartości na zmiany społeczne i różnorodne potrzeby wychowanków.

Liczne badania pokazują związek między inteligencją emocjonalną i kompetencjami społecznymi nauczycieli a sukcesem procesu nauczania i uczenia się. Na przykład Lauryne Alexis-Boyd (za: Llorent, Zych, Varo-Millán 2020) wykazała, że nieodpowiednie zarządzanie emocjami i sytuacjami społecznymi związanymi z działalnością dydaktyczną może negatywnie wpływać na życie emocjonalne nauczyciela. Dlatego autorka ta zasugerowała potrzebę opracowania programów szkolenia nauczycieli w zakresie zarządzania emocjami w ich działalności zawodowej.

Badania osobowości zawodowej, inteligencji emocjonalnej i kompetencji społecznych przeprowadzone wśród studentów pedagogiki przez Kwiatkowskiego wskazują na potrzebę uzupełnienia programu studiów o kursy z zakresu rozwijania inteligencji emocjonalnej przyszłych nauczycieli. Autor zwraca uwagę, że

[...] tego typu trening przyniósłby wymierne, pozytywne efekty nie tylko dla samych uczniów (którzy mogliby nawiązać z nauczycielem o wiele lepszą relację, a w związku z tym w większym stopniu korzystać z prowadzonych przez niego lekcji; ich inteligencja emocjonalna rozwijałaby się szybciej - codzienny kontakt $\mathrm{z}$ «inteligentnym emocjonalnie» 
nauczycielem-modelem byłby sam w sobie idealnym treningiem), ale także dla nauczycieli (Kwiatkowski 2015b: 143).

Reasumując, wydaje się, że w interesie nas wszystkich, począwszy od wychowanków i nauczycieli, a skończywszy na rodzicach i wszystkich obywatelach, leży dołożenie wszelkich starań, aby wyposażyć przyszłych i czynnych zawodowo nauczycieli w takie kompetencje, które pozwolą im na skuteczne radzenie sobie w codziennych, często nieprzewidywalnych i trudnych zadaniach, jakie mogą napotykać na swojej zawodowej drodze. Dodatkowo, aby wspierać rozwój kompetencji emocjonalno-społecznych swoich wychowanków, nauczyciele sami powinni prezentować wysoki poziom tych kompetencji.

Biorąc pod uwagę powyższe, konieczne jest kompleksowe kształcenie w zakresie kompetencji emocjonalnych i społecznych już na poziomie akademickim, co w dalszej perspektywie będzie miało pozytywny wpływ na całe społeczeństwo. Jak pokazują bowiem wyniki badań naukowych, wysoki poziom tych kompetencji jest niezbędny jako katalizator szybkich zmian społecznych (Lopes, Salovey 2004; Mayer, Cobb 2000).

Postulat autorek artykułu w sprawie poszerzenia treści kształcenia akademickiego o praktyczne zajęcia wzmacniające kompetencje społeczne odnosi się w sposób szczególny do procesu przygotowania zawodowego nauczycieli szkół specjalnych. Wyposażeni w niezbędne umiejętności społeczne absolwenci jako nauczyciele lepiej poradzą sobie $\mathrm{z}$ permanentną obawą o zdrowie i dobrostan podopiecznych, nie będą tak podatni na kryzysy, utratę satysfakcji z pracy i wypalenie zawodowe. To z kolei powinno pozytywnie wpłynąć na rozwój kompetencji ich podopiecznych $\mathrm{w}$ szkole $\mathrm{w}$ codziennym treningu społecznym.

\section{Bibliografia}

Argyle M. (1999). Psychologia stosunków międzyludzkich, przeł. W. Domachowski, Warszawa: Wydawnictwo Naukowe PWN.

Gil-Olarte P., Palomera R., Brackett M.A. (2006). Relating Emotional Intelligence to Social Competence and Academic Achievement in High School Students, „Psicothema”, t. 16, supplement, s. 118-123.

Goleman D. (1995). Emotional Intelligence, New York: Bantam Books. 
Goleman D. (1997). Inteligencja emocjonalna, przeł. A. Jankowski, Poznań: Media Rodzina.

Goleman, D. (2007). Inteligencja emocjonalna, wyd. jubileuszowe, Poznań: Media Rodzina.

Goleman, D. (1999). Inteligencja emocjonalna w praktyce, przeł. A. Jankowski, Poznań: Media Rodzina.

Guil R., Gil-Olarte P., Mestre J.M., Nuñez I. (2005). Inteligencia emocional y adaptación socioescolar, [w:] Psicología social y problemas sociales. Psicología Ambiental, Comunitaria y Educación, red. J. Romay, R. García, Madrid: Biblioteca Nuevas, s. 359-366.

Jaworowska A., Matczak A. (2005). Popularny Kwestionariusz Inteligencji Emocjonalnej PKIE. Warszawa: Pracownia Testów Psychologicznych PTP.

Jones D.E., Greenberg M.T., Crowley M.D. (2015), Early Social-Emotional Functioning and Public Health: The Relationship Between Kindergarten Social Competence and Future Wellness, „American Journal of Public Health", t. 105, nr 11, s. 2283-2290.

Knopp K. (2013). Kompetencje spoteczne - pomiar i aplikacja praktyczna, Warszawa: Ośrodek Rozwoju Edukacji, Instytut Psychologii UKSW.

Kwiatkowski S.T. (2015a), Innowacje we wspótczesnym systemie ksztatcenia nauczycieli w kontekście ksztattowania inteligencji emocjonalnej $i$ kompetencji spotecznych, [w:] Bliżej siebie. Edukacja i dialog w grupie niejednorodnej kulturowo, red. R. Nowakowska-Siuta, Warszawa: Wydawnictwo Naukowe ChAT, s. 93-110.

Kwiatkowski S.T. (2015b), Diagnoza wybranych różnic indywidualnych studentów pedagogiki w kontekście przysztych sukcesów w zawodzie nauczyciela, „Studia z Teorii Wychowania”, t. 6, nr 4(13), s. 127-159.

Kwiatkowski S.T. (2018a), Czynniki warunkujace radzenie sobie nauczycieli szkót podstawowych z wyzwaniami zawodowymi - relacja z badań, „Edukacja Ustawiczna Dorosłych”, nr 4(103), s. 90-108.

Kwiatkowski S.T. (2018b), Radzenie sobie ze stresem w zawodzie nauczycielaraport z badań, „Annales Universitatis Mariae Curie-Skłodowska. Sectio J. Paedagogia-Psychologia”, nr 31(3), s. 133-162.

Llorent V.J., Zych I., Varo-Millán J.C. (2020). Competencias socioemocionales autopercibidas en el profesorado universitario en España, „Educación XXI”, t. 23, nr 1, s. 297-318.

Lopes P., Salovey P. (2004). Toward a Broader Education: Social, Emotional, and Practical Skills, [w:] Building School Success on Social and Emotional Learning, red. J.E. Zins, R.P. Weissberg, M.C. Wang, H.J. Walberg (red.), New York: Teachers College Press, s. 79-93.

Márquez-González M., Izal M., Montorio I., Losada A. (2008). Experiencia y regulación emocional a lo largo de la etapa adulta del ciclo vital: análisis comparativo en tres grupos de edad, „Psicothema”, t. 20, nr 4, s. 616-622. 
Martowska K. (2012). Psychologiczne uwarunkowania kompetencji spotecznych, Warszawa: Wydawnictwo Liberi Libri.

Matczak A. (2007). Kwestionariusz Kompetencji Spotecznych KKS. Podręcznik, wyd. 2 uzupełnione, Warszawa: Pracownia Testów Psychologicznych.

Matczak A., Martowska K. (2013). Profil kompetencji spotecznych. PROKOS, Warszawa: Pracownia Testów Psychologicznych PTP.

Mayer J.D., Cobb C.D. (2000). Emotional Intelligence: What the Research Says, „Educational Leadership: Journal of the Department of Supervision and Curriculum Development”, t. 58, nr 3, s. 14-18.

Molero D., Ortega F., Moreno M.R. (2010). Diferencias en la adquisición de competencias emocionales en función del género, „Revista Electrónica de Investigación y Docencia (REID)”, nr 3, s. 165-172.

Nolen-Hoeksema S., Aldao A. (2011). Gender and Age Differences in Emotion Regulation Strategies and Their Relationship to Depressive Symptoms, „Personality and Individual Differences”, t. 51, nr 6, s. 704-708.

Riggio R. E. (1986). Assessment of basic social skills, „Journal of Personality and Social psychology", t. 51, s. 649-660.

Saarni C. (1999). Kompetencja emocjonalna i samoregulacja w dzieciństwie, [w:] Rozwój emocjonalny a inteligencja emocjonalna. Problemy edukacyjne, red. P. Salovey, D.J. Sluyter, przeł. M. Karpiński, Poznań: Dom Wydawniczy Rebis, s. 75-125.

Saarni C. (1999). The Development of Emotional Competence, New York: Guilford Press.

Saarni C. (2005). Spoteczny kontekst rozwoju emocjonalnego, [w:] Psychologia emocji, red. M. Lewis, J.M. Haviland-Jones, przeł. M. Kacmajor i in., Gdańsk: Gdańskie Towarzystwo Psychologiczne, s. 392-412.

Sadowska M., Brachowicz M. (2008). Struktura inteligencji emocjonalnej, [w:] Studia z psychologii w KUL, t. 15, red. P. Francuz, W. Otrębski, Lublin: Wydawnictwo KUL, s. 65-79.

Salovey P., Mayer J.D. (1999). Czym jest inteligencja emocjonalna?, [w:] Rozwój emocjonalny a inteligencja emocjonalna. Problemy edukacyjne, red. P. Salovey, D.J. Sluyter, przeł. M. Karpiński, Poznań: Dom Wydawniczy Rebis, s. 23-69.

Salovey P., Sluyter D.J. (red.) (1999). Rozwój emocjonalny a inteligencja emocjonalna. Problemy edukacyjne, przekł. M. Karpiński, Poznań: Dom Wydawniczy Rebis.

Salovey, P., Mayer, J.D. (1990). Emotional Intelligence, „Imagination, Cognition, and Personality", t. 9, nr 3, s. 185-211.

Smółka P. (2008). Kompetencje spoteczne - uwarunkowania i metody pomiaru, [w:] Szkice z psychologii różnic indywidualnych, red. W. Ciarkowska, W. Oniszczenko, Warszawa: Wydawnictwo Naukowe Scholar, s. $258-268$. 
Sutton, R., Wheatley K. (2003). Teachers' Emotions and Teaching: A Review of the Literature and Directions for Future Research, „Educational Psychology Review”, t. 15, nr 4, s. 327-358.

Taracha M. (2010). Inteligencja emocjonalna a wykorzystanie potencjatu intelektualnego, Lublin: Wydawnictwo Uniwersytetu Marii Curie-Skłodowskiej.

Trentacosta C.J, Izard C.E. (2007). Kindergarten Children's Emotion Competence as a Predictor of Their Academic Competence in First Grade, „Emotion", t. 7, nr 1, s. 77-88.

Wiszejko-Wierzbicka D. ( 2010). Niewykorzystana sfera: partycypacja spoteczna i obywatelska osób z ograniczeniami sprawności, Warszawa: Wydawnictwo Naukowe Scholar.

Zych I., Beltrán-Catalán M., Ortega-Ruiz R., Llorent V.J. (2017). Competencias sociales y emocionales de adolescentes involucrados en diferentes roles de bullying y cyberbullying, „Revista de Psicodidáctica”, t. 23, nr 2, s. 86-93.

\section{ADRES DO KORESPONDENCJI}

Dr Estera Twardowska-Staszek

Akademia Ignatianum w Krakowie

Instytut Nauk o Wychowaniu

e-mail: estera.twardowska-staszek@ignatianum.edu.pl

Mgr Małgorzata Alberska

Akademia Ignatianum w Krakowie Instytut Nauk o Wychowaniu

e-mail: malgorzata.alberska@ignatianum.edu.pl 